\title{
Removing of Toxic Cr (VI) Ions from wastewater using different adsorbents.
}

\author{
A.M. Ahmed ${ }^{1}$, Ahmed A. ABD EL-KHALEK ${ }^{2}$, Mona A. Derweesh ${ }^{3 *}$ \\ and Eman M. yousef ${ }^{2}$. \\ 1- Alex. University, Faculty of Science. \\ 2- Beni-Suef University, Faculty of Science. \\ 3- Tanta University, Faculty of Engineering. \\ * Corresponding author E-mail: mona_ahmed_dar2006@yahoo.com
}

\section{A B S T R A C T}

The removal of hexavalent chromium from wastewater on the Na-bentonite and activated carbon has been studied under static conditions. Experiments were carried out as a function of solution $\mathrm{pH}$, dosage of Na-bentonite and activated carbon contact time, agitation speed and temperature. The adsorption equilibrium for hexavalent chromium on to Na-bentonite is reached in $120 \mathrm{~min}$. the adsorption of hexavalent chromium is $\mathrm{pH}$ dependent in the $\mathrm{pH}$ range 1-4, the kinetic process of adsorption can be described by the pseudo-second order kinetic equation excellently and the adsorption isotherm be fitted to the langmuir and freundlich model by means of regression analyses very well. Finally it can be seen that Na-bentonite was favorite to be effective for removal of hexavalent chromium than activated carbon under the same experimental conditions.

\section{Keywords}

Na-bentonite; Hexavalent Chromium; Adsorption; Isotherm; Kinetics

\section{INTRODUCTION}

Industrial wastewater contaminated with heavy metal is commonly produced from many kinds of industrial processes there for, is this wastewater is not treated with a suitable process; it can cause a serious environmental problem in the natural eco-system $[1,2]$. Tannery effluent is a major source of aquatic pollution in Egypt with high hexavalent chromium [3]. Water of high quality is essential to human life and of acceptable quality is essential for agriculture, industrial, domestic and commercial uses. All this activities are also responsible for polluting the water. Billions of gallons of waste from all this sources are thrown to fresh water bodies everyday [4].

The requirement for water is increasing while slowly all the water resources are becoming unfit for use due to improper waste disposal [5]. The task of providing proper treatment facility for all polluting sources is difficult and also expensive; hence there is pressing demand for innovative technologies which are low cost, require low mentainence and are energy efficient [6]. The adsorption technique is economically 
favorable and technically easy to separate as the requirements of the control system is minimum [7].

Hexavalent chromium $\mathrm{Cr}$ (VI) compounds are being used in a wide variety of commercial processes and unregulated disposal of the chromium containing effluents has led to the contamination of soil, sediment, surface and ground waters. In trace amounts, chromium is considered an essential nutrient for numerous organisms, but at higher level, it is toxic and mutagenic. nearly $80 \%$ of the tanneries is engaged in the chrome tanning processes. Most of them discharge untreated water into the environment. In such aqueous waste, $\mathrm{Cr}(\mathrm{VI})$ is present as either dichromate $\left(\mathrm{Cr}_{2} \mathrm{O}_{7}\right)^{-2}$ in acidic environments or as chromate $\left(\mathrm{CrO}_{4}\right)^{-1}$ in alkaline environments. Chromium compounds were employed in textile coloring and leather tanning processes. The principle chromium emissions into surface waters are from metal finishing processes such as electro- plating, pickling and bright dipping [8].

Pollution of soils occurs as result of the dumping of chromate wastes such as those from tanniers or electroplating and from sewage sludge disposal on land [9]. Uncontrolled emissions have greater potential for contaminating the fresh waters with relatively toxic from $\mathrm{Cr}(\mathrm{VI})$, which exists only as oxy species and is strongly oxidizing other small discharges of $\mathrm{Cr}(\mathrm{VI})$ are from the additive in circulating waters, Landry chemicals [10].

In this article, the technical feasibility of low cost (adsorption), and locally available adsorbents bentonite and activated carbon for heavy metal removal $\mathrm{Cr}$ (VI) ion, from contaminated water has been reviewed. This work is intended to remove $\mathrm{Cr}(\mathrm{VI})$ from aqueous solutions on to bentonite and activated carbon as an effective and low cost.

In the present investigation, to estimate the amount of chromium ions present in its aqueous solutions after treatment and the removal of chromium from wastewater using bentonite and activated carbon as an adsorbents are attempted.

The present work is also aimed at fixing the optimal conditions such as $\mathrm{pH}$, equilibrium time (for batch mode technique), dosages of adsorbent and initial concentration on the adsorption efficiency of $\mathrm{Cr}(\mathrm{VI})$ ion from wastewater by bentonite and activated carbon besides for effective removal of chromium; To evaluate the equilibrium of adsorption process using Langmuir and freundlich isotherms. Meanwhile, the kinetics of $\mathrm{Cr}(\mathrm{VI})$ ion adsorption on bentonite and activated carbon also analyzed using pseudo-second order kinetic models[11]. 


\section{MATERIALS AND METHODS}

\subsection{MATERIALS AND REAGENTS}

All chemicals used in the present investigation were either of analytical reagent (AR) or laboratory reagent (LR) grade and were used as received. $\mathrm{K}_{2} \mathrm{Cr}_{2} \mathrm{O}_{7}, \mathrm{H}_{2} \mathrm{SO}_{4}$ (98\% w/w) supplied by BDH chemicals Ltd. Distilled water was used in all preparations. Potassium dichromate $\left(\mathrm{K}_{2} \mathrm{Cr}_{2} \mathrm{O}_{7}\right)$ with $99 \%$ purity and deionized water were used to prepare synthetic chromium containing wastewater. Powder activated carbon (PAC) produced from natural origin by ADWIC was used as adsorbent as well as American Wyoming calcium bentonite used in Alexandria Company for Refractories.

\subsection{ADSORBENTS ANALYSIS}

Two different materials were used in order to examine the removal of $\mathrm{Cr}^{+6}$ from aqueous solutions. Powder activated carbon (PAC) and bentonite (clay) were supplied from ADWIC and Alexandria Company for Refractories, respectively. The surface area and particle size analyses for the two adsorbents were checked (Table 1). Elemental analysis for bentonite was evaluated using X-ray fluorescence (Philips PW 1390) as shown in (Table 2).

Table 1.Surface area and particles size analysis of activated carbon and bentonite.

\begin{tabular}{|c|c|c|c|c|}
\hline Adsorbents & \multicolumn{2}{|c|}{ Activated Carbon } & \multicolumn{2}{|c|}{ Bentonite } \\
\hline $\begin{array}{c}\text { Surface Area (BET) } \\
\text { Nova } 2000\end{array}$ & \multicolumn{2}{|c|}{$931.9 \mathrm{~m}^{2} / \mathrm{g}$} & \multicolumn{2}{|c|}{$119.8 \mathrm{~m}^{2} / \mathrm{g}$ (dry) } \\
\hline $\begin{array}{c}\text { Particle size (XRD) } \\
\text { Philips PW } 1730\end{array}$ & $\begin{array}{c}\text { Size } \\
\text { (micrometer) } \\
32-16 \\
16-8 \\
8-4 \\
<2\end{array}$ & $\begin{array}{c}\text { Wt. \% } \\
2.75 \\
55.89 \\
16.03 \\
4.19\end{array}$ & $\begin{array}{c}\text { Size } \\
\text { (micrometer) } \\
>63 \\
63-32 \\
32-16 \\
16-8 \\
8-4 \\
4-2 \\
<2\end{array}$ & $\begin{array}{c}\text { Wt. \% } \\
1 \\
1 \\
2 \\
3 \\
2 \\
4 \\
87\end{array}$ \\
\hline
\end{tabular}


Table 2. Elemental analysis for bentonite was evaluated using $x$-ray fluorescence (Philips PW 1390).

\begin{tabular}{|c|c|}
\hline Oxides (wt.\%) & Bentonite \\
\hline $\mathrm{SiO}_{2}(\%)$ & 55.89 \\
\hline $\mathrm{Al}_{2} \mathrm{O}_{3}(\%)$ & 16.03 \\
\hline $\mathrm{Fe}_{2} \mathrm{O}_{3}(\%)$ & 4.19 \\
\hline $\mathrm{CaO}(\%)$ & 3.25 \\
\hline $\mathrm{MgO}(\%)$ & 2.75 \\
\hline $\mathrm{K}_{2} \mathrm{O}(\%)$ & 0.49 \\
\hline $\mathrm{Na}_{2} \mathrm{O}(\%)$ & 0.34 \\
\hline $\mathrm{TiO}_{2}(\%)$ & 0.15 \\
\hline $\mathrm{P}_{2} \mathrm{O}_{5}(\%)$ & 0.086 \\
\hline $\mathrm{SO}_{3}(\%)$ & 0.23 \\
\hline $\mathrm{LOI}^{(\%)}$ & 17.2 \\
\hline
\end{tabular}

\subsection{APPARATUS AND TECHNIQUE}

Magnetic hot plate stirrer was used to stir the heavy metal solution with adsorbents (activated carbon or bentonite). A definite volume of heavy metal ion solution with a known initial concentration is stirred with a definite amount of adsorbent for certain time at fixed temperature and agitation rate. $\mathrm{pH}$ of the solution was measured by digital pH meter (Model $\mu \mathrm{pH}$ system-361, India).

\subsection{EXPERIMENTAL PROCEDURES}

Potassium dichromate $\left(\mathrm{K}_{2} \mathrm{Cr}_{2} \mathrm{O}_{7}\right)$ and redistilled water were used to prepare a stock solution with a concentration of $1000 \mathrm{ppm} \mathrm{Cr}(\mathrm{VI})$ which was diluted for preparation of standard and test solutions. Several solutions with different initial concentrations of potassium dichromate (50, 100, 200, 300 and $400 \mathrm{ppm}$ ) were prepared. The required $\mathrm{pH}$ was adjusted by drop wise addition of $0.1 \mathrm{~N} \mathrm{H}_{2} \mathrm{SO}_{4}$ depending on the acidity of the sample. All experiments were carried out at $25^{\circ} \mathrm{C}$ by adding different amounts of adsorbents $(0.1,0.3,0.5,0.7$ and $1.0 \mathrm{~g})$ to different concentrations of $250 \mathrm{ml}$ of heavy metals ions solution. The agitation rate for all experiments was $200 \mathrm{rpm}$ and the residence time was $(0,15,30,45,60,75,90$ and $120 \min )$. 
$1 \mathrm{ml}$ of Sample was taken from reaction solution and diluted to $10 \mathrm{ml}$ by redistilled water, the solution is then separated from the adsorbents by using filter paper (Watman No. 40) and the residual $\mathrm{Cr}^{+6}$ concentration in the solution is then determined by atomic-absorption spectrophotometer (AAS).

The effects of several parameters, such as contact time, initial concentration, adsorbent doses, $\mathrm{pH}$ and temperature on the adsorption of $\mathrm{Cr}(\mathrm{VI})$ ions on activated carbon and bentonite were studied.

\subsection{ANALYTICAL METHOD}

Atomic absorption spectrophotometry utilizes the phenomenon that atoms absorb radiation of particular wavelength. By atomic-absorption spectrophotometer AAS (Model, AA55; Varian Inc., USA), The metals in water sample can be analyzed. It detects the concentration of $\mathrm{Cr}(\mathrm{VI})$ in ppm level in the solution and the volume of sample required is only $1 \mathrm{ml}$ for one analysis.

\subsection{DATA ANALYSIS}

The uptake of $\mathrm{Cr}(\mathrm{VI})$ ions was calculated from the mass balance, which was stated as the amount of solute adsorbed onto the solid. It equals the amount of solute removed from the solution. Mathematically, it can be expressed by Eq. (1):

$$
\mathrm{q}_{\mathrm{e}}=\left(\mathrm{C}_{\mathrm{i}}-\mathrm{C}_{\mathrm{e}}\right) / \mathrm{S}
$$

where:

$\mathrm{q}_{\mathrm{e}}$ the heavy metal ions concentration adsorbed by an adsorbent at equilibrium ( $\mathrm{mg}$ of metal ion/g of adsorbent)

$\mathrm{C}_{\mathrm{i}}$ is the initial concentration of metal ions in the solution $(\mathrm{mg} / \mathrm{L})$.

$\mathrm{C}_{\mathrm{e}}$ is the equilibrium concentration or final concentration of metal ions in the solution $(\mathrm{mg} / \mathrm{L})$.

S the dosage concentration and it is expressed by Eq. (2):

$$
\mathrm{S}=\mathrm{m} / \mathrm{V}
$$

where $\mathrm{V}$ is the initial volume of metal ions solution used $(\mathrm{L})$ and $\mathrm{m}$ is the weight of dried used adsorbent $(\mathrm{g})$. 
The percentage of adsorption (\%) is calculated using equation (3):

$$
\% \text { adsorption }=\left[\left(\mathrm{C}_{\mathrm{i}}-\mathrm{C}_{\mathrm{e}}\right) / \mathrm{C}_{\mathrm{i}}\right] \times 100
$$

\section{RESULTS AND DISCUSION}

\subsection{EFFECT OF CONTACT TIME}

The experiment of adsorption as a function of contact time was conducted at known initial concentration of $\mathrm{Cr}(\mathrm{VI})$ metal ion, dose of $4 \mathrm{~g} / \mathrm{L}$ for both activated carbon and bentonite (Fig 1). It is easily seen from Fig 1 that the percentage removal of $\mathrm{Cr}(\mathrm{VI})$ metal ions increased with increasing the contact time. The $\%$ removal was $73 \%$ for activated carbon and $77 \%$ for bentonite after $120 \mathrm{~min}$. It is clear that, at the beginning \% removal increased rapidly in few minutes. By increasing contact time, $\%$ removal increased lightly and slowly till reach maximum value and this can be explained on the basis that, initially a large number of vacant surface sites may be available for adsorption of metal ions, and by time the surface sites become exhausted [12]. These results indicate that the activated carbon and bentonite have a very strong capacity for adsorption of $\mathrm{Cr}(\mathrm{VI})$ ions in solution.

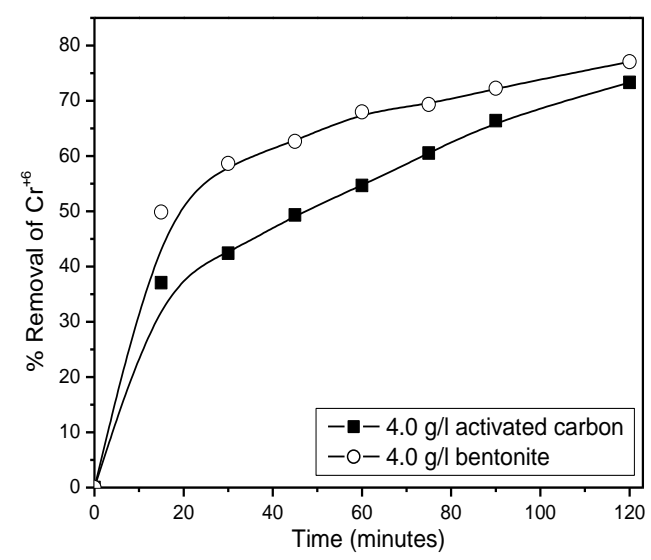

Fig 1. Effect of contact time on $\mathrm{Cr}^{+6}$ removal (conditions; adsorbate initial conc., $400 \mathrm{mg} / \mathrm{L}$; pH, 2.0; adsorbents dose, 4 g/L; agitation speed, $200 \mathrm{rpm}$ and temperature, 25 $\left.{ }^{\circ} \mathrm{C}\right)$.

\subsection{Effect of Adsorbent Dose}

The percentage adsorption of $\mathrm{Cr}^{+6}$ on activated carbon and bentonite was studied at different adsorbent doses $(0.4,1.2,2.0,2.8$ and $4.0 \mathrm{~g} / \mathrm{L})$, keeping $\mathrm{pH}$ (2), temperature $\left(25^{\circ} \mathrm{C}\right)$, contact time $(120 \mathrm{~min})$ and initial $\mathrm{Cr}^{+6}$ ions 
concentration of $(400 \mathrm{mg} / \mathrm{L})$ constant Fig 2. The results showed that with increasing in adsorbent dose, percentage adsorption of $\mathrm{Cr}^{+6}$ was increased and the maximum removal was observed with adsorbent $4 \mathrm{mg} / \mathrm{L}$ for activated carbon and bentonite. Increasing the percentage of adsorption with adsorbent dose may be due to the increase in adsorbent surface area and availability of more adsorption sites [13,14]. But unit adsorption was decreased with increasing in adsorbent dose Fig 3. This is may be due to overlapping of adsorption sites as a result of overcrowding of adsorbent particles [14].

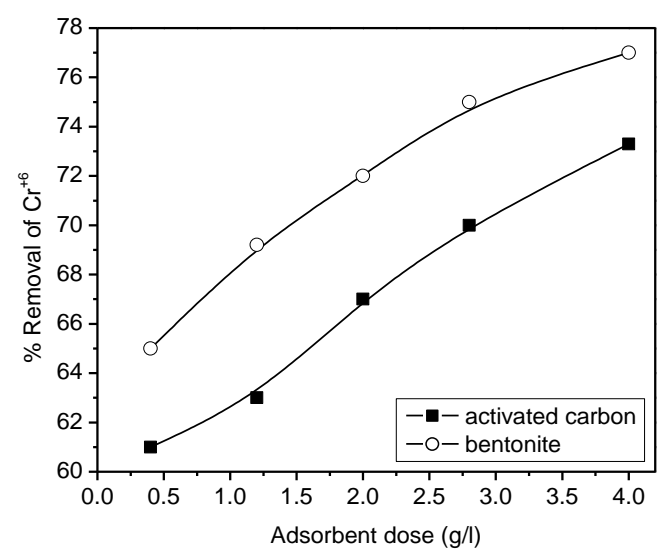

Fig 2. The effect of variant activated carbon or bentonite adsorbent dosage $(0.4$, $1.2,2.0,2.8$, and $4.0 \mathrm{~g} / \mathrm{l}$ ) on the removal of $400 \mathrm{mg} / 1 \mathrm{Cr}^{+6}$ ions from wastewater at contact time, $2 \mathrm{~h}$, temperature, $25^{\circ} \mathrm{C}$ and agitation speed, $200 \mathrm{rpm}$.

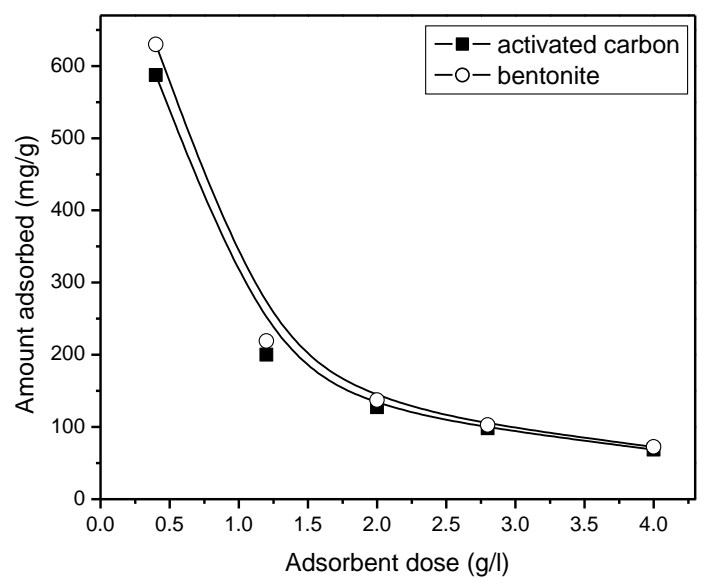

Fig 3. The effect of variant activated carbon or bentonite adsorbent dosage

$(0.4,1.2,2.0,2.8$, and $4.0 \mathrm{~g} / \mathrm{L})$ on the quantity adsorbed of $400 \mathrm{mg} / \mathrm{L} \mathrm{Cr}^{+6}$ ions from wastewater at contact time, $2 \mathrm{~h}$, temperature, $25^{\circ} \mathrm{C}$ and agitation speed, $200 \mathrm{rpm}$. 


\subsection{EFFECT OF INITIAL CHROMIUM (VI) IONS CONCENTRATION}

The initial heavy metal ion concentration is an important parameter in adsorption since a certain amount of adsorbent can adsorb a certain amount of heavy metal. The percentage removal of $\mathrm{Cr}^{+6}$ was studied by varying $\mathrm{Cr}^{+6}$ concentration from 50 to $300 \mathrm{mg} / \mathrm{L}$ with $4 \mathrm{~g} / \mathrm{L}$ adsorbent doses of activated carbon and bentonite at $\mathrm{pH}(2)$, temperature $\left(25^{\circ} \mathrm{C}\right)$ and contact time $(120 \mathrm{~min})$ is illustrated in Fig 4.

The results presented in Fig.4, showed that the percentage $\mathrm{Cr}^{+6}$ adsorption was decreased with increasing in initial concentration. But the actual amount $\mathrm{of}^{\mathrm{Cr}^{+6}}$ adsorbed per unit mass of the adsorbent was increased with increasing in $\mathrm{Cr}^{+6}$ concentrations in the test solution, Fig 5. According to these results, the initial $\mathrm{Cr}^{+6}$ ions concentration plays an important role in the adsorption capacities. Higher concentrations of metal ion were used to study the maximum adsorption capacity of adsorbent $[15,16]$.

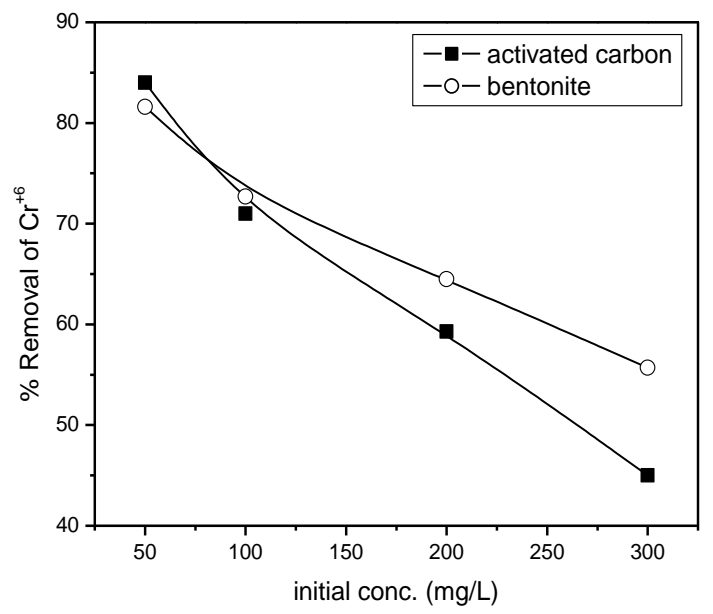

Fig 4. The effect of initial concentration (namely 50, 100, 200 and $300 \mathrm{mg} / \mathrm{l}$ ) on removal of $\mathrm{Cr}^{+6}$ ions (conditions; adsorbents dose, $4 \mathrm{~g} / \mathrm{l}$; agitation speed, $200 \mathrm{rpm}$ and temperature, $25^{\circ} \mathrm{C}$ ). 


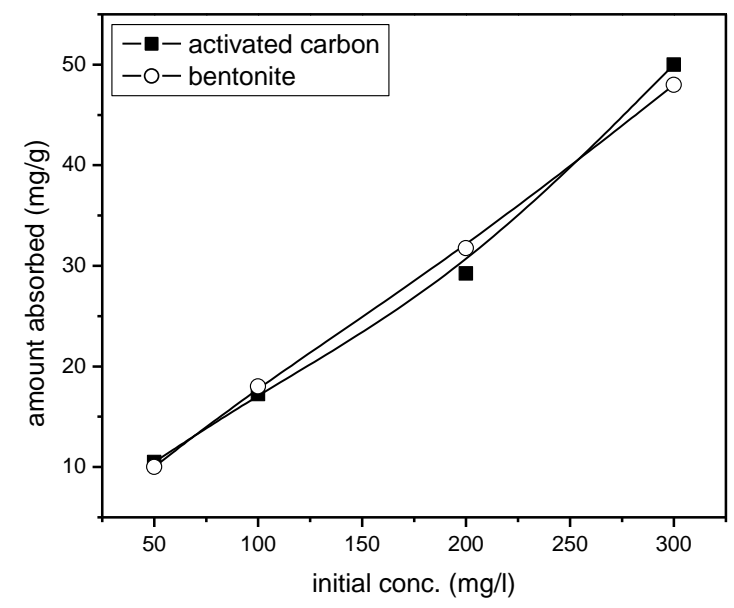

Fig 5. The effect of initial concentration (namely 50, 100, 200 and $300 \mathrm{mg} / \mathrm{l}$ ) on quantity adsorbed of $\mathrm{Cr}^{+6}$ ions (conditions; adsorbents dose, $4 \mathrm{~g} / \mathrm{l}$; agitation speed, 200 rpm and temperature, $25^{\circ}$

\subsection{EFFECT OF pH ON THE UPTAKE OF $\mathrm{Cr}^{+6}$}

The $\mathrm{pH}$ of the solution is an important variable which controls the adsorption of the metal ions at the solid-water interface. Hence, the influence of $\mathrm{pH}$ on the adsorption of $\mathrm{Cr}^{+6}$ on activated carbon and bentonite was examined in the $\mathrm{pH}$ range 14. The results were presented in Fig 6, it showed that the adsorption capacities of $\mathrm{Cr}^{+6}$ onto both adsorbents increases significantly with decreasing $\mathrm{pH}$ value and the maximum removals of $\mathrm{Cr}^{+6}$ by both adsorbents for contact time (120 min) were carried out at $\mathrm{pH}$ (2). The improved removal of chromium(VI) at low $\mathrm{pH}$ is probably due to reduction of hexavalent chromium to trivalent chromium [17], Eq. (4) .

$$
\mathrm{Cr}_{2} \mathrm{O}_{7}^{-2}+14 \mathrm{H}^{+}+6 \mathrm{e}^{-1} \rightarrow 2 \mathrm{Cr}^{+3}+7 \mathrm{H}_{2} \mathrm{O}
$$

Also at low $\mathrm{pH}$, there is presence of a large number of $\mathrm{H}^{+}$ions, which in turn neutralize the negatively charged adsorbent surface thereby reducing hindrance to the diffusion of dichromate ions [18]. 


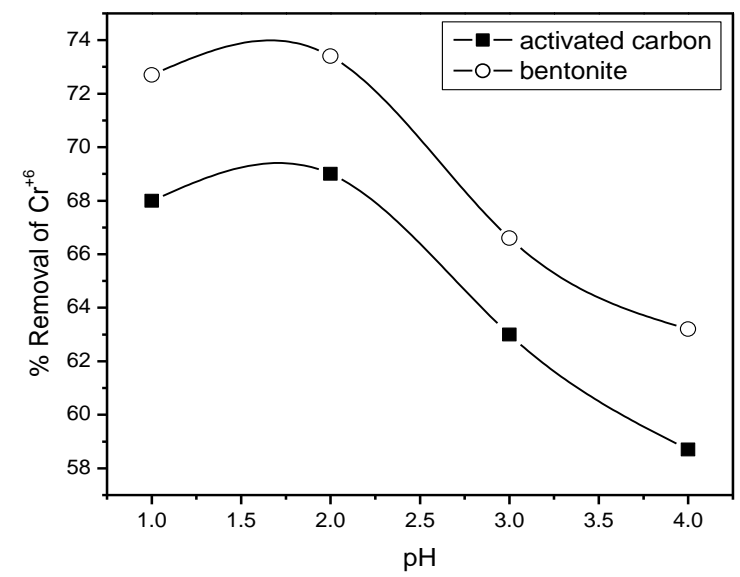

Fig 6. Effect of $\mathrm{pH}$ for the adsorption of $\mathrm{Cr}(\mathrm{VI})$ ions onto activated carbon and bentonite at $25^{\circ} \mathrm{C}$.

\subsection{EFFECT OF TEMPERATURE}

Fig 7 indicates the effect of temperature on the removal efficiency of $\mathrm{Cr}^{+6}$ ions from wastewater using activated carbon and bentonite. Four different temperatures were considered in this study $\left(25,30,35\right.$ and $\left.40^{\circ} \mathrm{C}\right)$. The figure showed that the removal efficiency increases by increasing the temperature, where the maximum adsorption (76\% approx.) is achieved at $40^{\circ} \mathrm{C}$ in case of activated carbon. The augmentation of the removal efficiency by stepping up the temperature are due to: Firstly, the higher temperature activates the metal ions for enhancing adsorption at the coordinating sites of the adsorbent, and the metal cation more faster [19, 20]. Secondly, acceleration of some originally slow step(s) and creation of some new activation sites on the adsorbent surface [21]. Herein, the phenomenon can be observed in both adsorbents, but activated carbon is affected much higher than in case bentonite Fig 7 . 


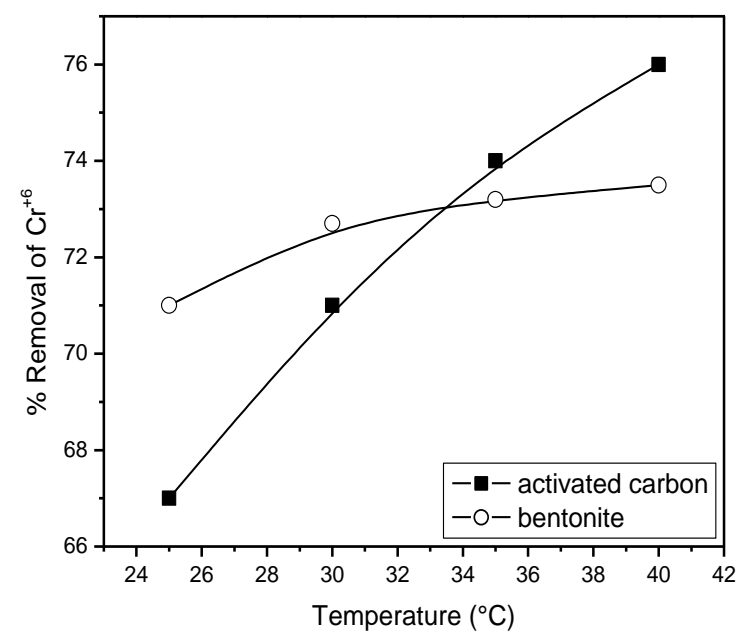

Fig 7. The effect of temperature between 25 and $40{ }^{\circ} \mathrm{C}$ for the removal of $\mathrm{Cr}^{+6}$ ions from wastewater (conditions; adsorbate initial conc., $400 \mathrm{mg} / \mathrm{L} ; \mathrm{pH}, 2.0$; adsorbents dose, $4 \mathrm{~g} / \mathrm{L}$; agitation speed, $200 \mathrm{rpm}$ and contact time $2 \mathrm{~h}$ ).

\subsection{ADORPTION ISOTHERMS}

Several models have been used in the literature to describe the experimental data of adsorption isotherm. The Langmuir and Freundlich models are the most frequently employed to describe equilibrium [22]. The Langmuir isotherm is based on the theoretical principle that only a single adsorption layer exists on an adsorbent and it represents the equilibrium distribution of metal ions between the solid and liquid phases. The basic assumption of the Langmuir adsorption process is the formation of a monolayer of adsorbate on the outer surface of the adsorbent and after that no further adsorption take place. The Langmuir-type isotherm remains to be the most widely used for practical application. The Langmuir isotherm for pure component adsorption can be obtained from Eq. (5):

$$
\mathrm{C}_{\mathrm{e}} / \mathrm{q}_{\mathrm{e}}=1 /\left(\mathrm{q}_{\max } \mathrm{b}\right)+\left(1 / \mathrm{q}_{\max }\right) \mathrm{C}_{\mathrm{e}}
$$

Where $q_{\max }$ is the maximum metal ions uptake per unit mass of adsorbent $(\mathrm{mg} / \mathrm{g})$, which is related to the adsorption capacity and $b$ is Langmuir constant $(\mathrm{L} / \mathrm{mol})$ which is exponentially proportional to the heat of adsorption and related to the adsorption intensity. Therefore, a plot of $C_{e} / q_{e}$ versus $C_{e}$ gives a straight line of slop $1 / q_{\max }$ and intercept $1 /\left(\mathrm{q}_{\max } \mathrm{b}\right)$ as shown in Fig 8. 
Zeldowitsch (1934) [22], assuming an exponentially decaying function of site density with respect to heat of adsorption and obtained the classical empirical isotherm, Eq. (6):

$$
\ln q_{\mathrm{e}}=\ln \mathrm{K}_{\mathrm{f}}+1 / \mathrm{n} \ln \mathrm{C}_{\mathrm{e}}
$$

This is known as Freundlich isotherm. The Freundlich adsorption isotherm is an indicator of the extent of heterogeneity of the adsorbent surface, where the Freundlich constants $K_{f}$ and $n$, which respectively indicating the adsorption capacity and the adsorption intensity, were calculated from the intercept and slope of the plot of $\mathrm{lnq}_{\mathrm{e}}$ versus $\ln C_{\mathrm{e}}$ as shown in Fig 9.

This Freundlich type behavior is indicative of surface heterogeneity of the adsorbents, i.e the adsorptive sites (surface of activated carbon and bentonite) are made up of small heterogeneous adsorption patches that are homogeneous in themselves. The activation of adsorption site takes place, leading to increased adsorption probably through the surface exchange mechanism.

The calculated results of Langmuir and Freundlich isotherm constants are given in table 3 .

It can be seen that the Freundlich model yields a much better fit than the Langmuir model, when the $R^{2}$ values are compared in table 3 . This suggests that the boundary layer thickness is increased. The Freundlich constant $K_{f}$ indicates the sorption capacity of the sorbent. From table 3, the values of $K_{f}$ are 1.84 and 1.58 for activated carbon and bentonite, respectively.

Furthermore, the value of $n$ is 2.26 and 1.78 for activated carbon and bentonite, respectively. It is noted that the values of $\mathrm{n}$ are bigger than 1 , reflecting the favorable adsorption. On the other hand, the $q_{\max }$ and the adsorption intensity values of bentonite are higher than activated carbon. The calculated $b$ values indicate the interaction forces between bentonite surface and $\mathrm{Cr}^{+6}$ ions are stronger than in case of activated carbon, this means that the bentonite is more powerful adsorbent than activated carbon. These results indicate that both adsorbents have a very strong adsorption capacity towards $\mathrm{Cr}^{+6}$ ions. 
Table 3.Langmuir and Freundlich isotherm constants for the adsorption of $\mathrm{Cr}^{+6}$ on activated carbon and bentonite at constant temperature $25^{\circ} \mathrm{C}$.

\begin{tabular}{|c|c|c|c|c|c|c|}
\hline \multirow{2}{*}{ Adsorbent } & \multicolumn{3}{|c|}{$\begin{array}{c}\text { Langmuir Isotherm } \\
\text { constants }\end{array}$} & \multicolumn{3}{c|}{$\begin{array}{c}\text { Freundlich Isotherm } \\
\text { constants }\end{array}$} \\
\cline { 2 - 7 } & $\begin{array}{c}\mathrm{q}_{\max } \\
(\mathrm{mg} / \mathrm{g} \\
)\end{array}$ & $\begin{array}{c}\mathrm{b} \\
(\mathrm{L} / \mathrm{mol})\end{array}$ & $\mathrm{R}^{2}$ & $\mathrm{~K}_{\mathrm{f}}$ & $\mathrm{n}$ & $\mathrm{R}^{2}$ \\
& $(\mathrm{mg} / \mathrm{g})$ & & \\
\hline $\begin{array}{c}\text { Activated } \\
\text { Carbon }\end{array}$ & 38.17 & 0.0252 & 0.9686 & 1.8446 & 2.26 & 0.9953 \\
\hline Bentonite & 48.83 & 0.0377 & 0.9658 & 1.5826 & 1.78 & 0.9995 \\
\hline
\end{tabular}

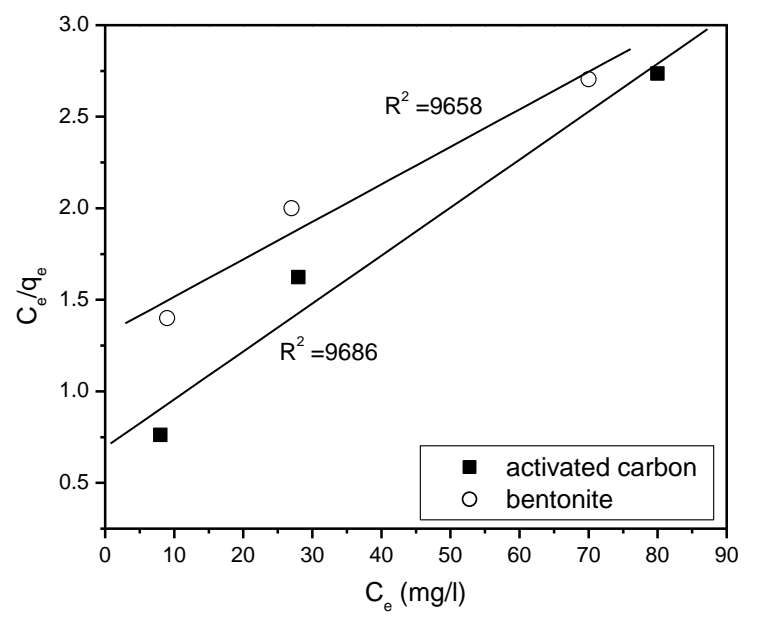

Fig 8. The linarized Langmuir adsorption isotherm for $\mathrm{Cr}^{+6}$ ions adsorption by activated carbon and bentonite at constant temperature $25^{\circ} \mathrm{C}$ and contact time $2 \mathrm{~h}$. 


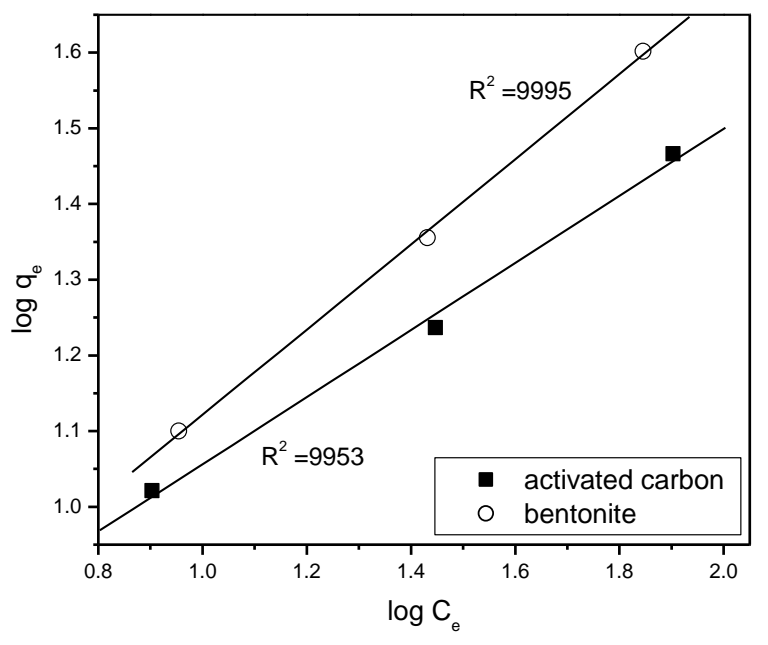

Fig 9. The linarized Freundlich adsorption isotherm for $\mathrm{Cr}^{+6}$ ions adsorption by activated carbon and bentonite at constant temperature $25^{\circ} \mathrm{C}$ and contact time $2 \mathrm{~h}$.

\subsection{THERMODYNAMIC PARAMETERS}

Thermodynamic parameters such as free energy $\left(\Delta \mathrm{G}^{\circ}\right)$, enthalpy $\left(\Delta \mathrm{H}^{\circ}\right)$ and entropy $\left(\Delta \mathrm{S}^{\circ}\right)$ changes of adsorption can be evaluated from the following equations (7, 8):

$$
\begin{gathered}
\mathrm{K}_{\mathrm{c}}=\mathrm{C}_{\mathrm{Ae}} / \mathrm{C}_{\mathrm{e}} \\
\Delta \mathrm{G}^{\circ}=-\mathrm{RT} \ln \mathrm{K}_{\mathrm{c}}
\end{gathered}
$$

Where $K_{c}$ is the equilibrium constant and $C_{A e}$ and $C_{e}$ (both in $m g / L$ ) are the equilibrium concentrations for solute on the sorbent and in the solution, respectively. The $K_{c}$ values are used in Eqs. (7) and (8) to determine the $\Delta \mathrm{G}^{\circ}, \Delta \mathrm{H}^{\circ}$ and $\Delta \mathrm{S}^{\circ}$ the $\mathrm{K}_{\mathrm{c}}$ may be expressed in terms of the $\Delta \mathrm{H}^{\circ}\left(\mathrm{kj} \mathrm{mol}^{-1}\right)$ and $\Delta \mathrm{S}^{\circ}\left(\mathrm{kj} \mathrm{mol}^{-1} \mathrm{~K}^{-1}\right)$ as a function of temperature, Eq. (9):

$$
\ln K_{c}=-\Delta H^{\circ} / R T+\Delta S^{\circ} / R
$$

Thermodynamic parameters such as free energy of sorption $\left(\Delta \mathrm{G}^{\circ}\right)$, the heat of sorption $\left(\Delta \mathrm{H}^{\circ}\right)$ and standard entropy $\left(\Delta \mathrm{S}^{\circ}\right)$ changes during the sorption process were calculated using Eqs. (7) and (8) on a temperature range of $25-40^{\circ} \mathrm{C}$ at initial concentration $50 \mathrm{mg} / \mathrm{L}$ of $\mathrm{Cr}^{+6}$ and dose $4 \mathrm{~g} / \mathrm{L}$ for activated carbon and bentonite. 
$\left(\Delta \mathrm{H}^{\circ}\right)$ and $\left(\Delta \mathrm{S}^{\circ}\right)$ were obtained from the slope and intercept of a plot of $\ln \mathrm{K}_{\mathrm{c}}$ against 1/T (Fig 10). The values of these parameters were recorded in table 4.

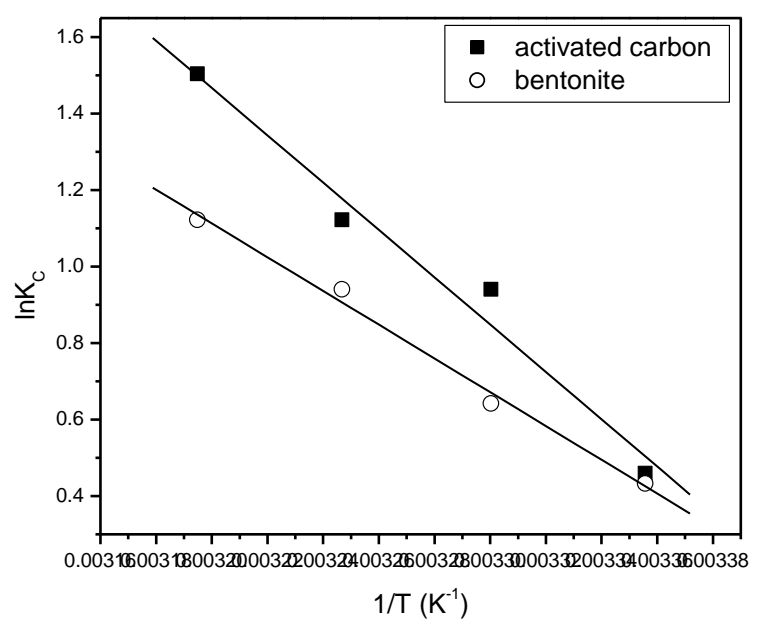

Fig 10. A plot of $\ln \mathrm{K}_{\mathrm{C}}$ against $1 / \mathrm{T}$ for $\mathrm{Cr}^{+6}$ adsorption for $50 \mathrm{mg} / \mathrm{l}$ initial concentration at constant adsorbents dose $4 \mathrm{~g} / \mathrm{L}$.

Table 4.Thermodynamic parameters for the adsorption of $\mathrm{Cr}(\mathrm{VI})$ onto activated carbon and bentonite.

\begin{tabular}{|c|c|c|c|c|c|c|}
\hline \multirow{2}{*}{ Adsorbent } & \multirow{2}{*}{$\Delta \mathrm{H}^{\circ}\left(\mathrm{kj} \mathrm{mol}^{-1}\right)$} & $\begin{array}{c}\Delta \mathrm{S}^{\circ}(\mathrm{kj} \\
\left.\mathrm{mol}^{-1} \mathrm{~K}^{-1}\right)\end{array}$ & \multicolumn{4}{|c|}{$\Delta \mathrm{G}^{\circ}\left(\mathrm{kj} \mathrm{mol}^{-1}\right)$} \\
\cline { 4 - 7 } & & & $25^{\circ} \mathrm{C}$ & $30^{\circ} \mathrm{C}$ & $35^{\circ} \mathrm{C}$ & $40^{\circ} \mathrm{C}$ \\
\hline $\begin{array}{c}\text { Activated } \\
\text { carbon }\end{array}$ & 51.45 & 0.1776 & -1.24 & -2.12 & -3.00 & -3.89 \\
\hline Bentonite & 36.72 & 0.1268 & -1.06 & -1.70 & -2.33 & -2.71 \\
\hline
\end{tabular}

The negative values of $\Delta \mathrm{G}^{\circ}$ indicate the spontaneous nature of the process and more negative value with increase of temperature shows that an increase in temperature favors the sorption process. The positive values of $\Delta \mathrm{H}^{\circ}$ indicate that the sorption process was endothermic in nature and the positive values of $\Delta S^{\circ}$ show the increased randomness at solid/solution interfaces during the adsorption of metal on both adsorbents and also reflects the affinity of activated carbon and bentonite toward $\mathrm{Cr}^{+6}$ ions under consideration. It is also suggested that the positive values of entropy indicate some structural changes in the adsorbate and adsorbent [23-25]. 


\section{COCLUSION}

Both adsorbents can be successfully used for removing of chromium (VI) ions from wastewater. The maximum adsorption percentage of $\mathrm{Cr}(\mathrm{VI})$ ions using both adsorbents were achieved within $120 \mathrm{~min}$. The adsorption percentages $\mathrm{of}^{\mathrm{Cr}}{ }^{+6}$ ions increase sharply by increasing adsorbent doses. As the initial concentration of ions increase the percentage removal using activated carbon and bentonite decreases. The best temperature for the maximum adsorption is found to be $30-40^{\circ} \mathrm{C}$ for activated carbon, while the adsorption using bentonite is less affected by increasing temperature. The maximum removals of $\mathrm{Cr}(\mathrm{VI})$ by both adsorbents were carried out at $\mathrm{pH}$ 2. The obtained experimental data has been well described by Langmuir and Freundlich isotherm models into both activated carbon and bentonite.

Different thermodynamic parameters, viz., $\Delta \mathrm{H}^{\circ}, \Delta \mathrm{S}^{\circ}$ and $\Delta \mathrm{G}^{\circ}$ have also been evaluated and it has been found that the sorption was feasible, spontaneous and endothermic in nature. The positive value of the entropy change, suggests the increased randomness.

\section{REFERENCES}

[1] Ayad M. jebur almamoori*, fikrat m. hassana and thaer i. kassimb,2012" impact of industrial waste on the properties of one major drainage in the region of the middle euphrates / Iraq" int. j. chem. Sci.: 10(4)( 2012) 1785-1798

[2]Park Heung Jai, Jeong Seong Wook,Yang Jae Kyu, Kim Boo Gil, Lee Seung Mok" Removal of heavy metals using eggshell", Journal of Environmental Sciences 19(2007) 1436-1441.

[3]Mohamed Nasif Abbas, Firas Saeed Abbas, Hala Husham Nussarat, Safaa Neamat Hussein, "Synthesis of Promoted Catalyst from Iraqi rice"

[4]Mohamed Ali Zulfikar, EdehDieke Mariske, and samitha Dewi Djajanti,"Adsorption of Ligosulfnate compounds using powder eggshell",songkanakarin

j.sci.Technol,34(3),May - June (2013 ) 309-316

[5]Suresh Gupta and BV Babu, 2013,"Adsorbtion of chromium (VI) by low-cost adsorbent prepared from tamarind seeds" Birla institude of technology and science, india, 2013

[6]Rajendran. A and C.Mansiya,2011, "Extraction of Chromium from tannery effluents using waste eggshell materials as adsorbent" , British Journal of environment and climate change ,1(2),(2011) 44-52 
[7]Renge,V.C. S.V. Khedkar and Shraddha V Pande, " Removal of heavey metals from waste water using low-cost adsorbent" Sci. Revs. Chem. Common,: 2(4) , (2012) 580 -584 ISSN 2277-2669

[8] Rajendran, A. (2010). Applicability of an ionic liquid in the removal of chromium from tannery efflluents: Agreen chemical approch, Affrican journal of pure and Applied Chemistery., 4(6), 100-103

[9]Ambasht , R.S. (1983). Ecological Consideration of water pollution, Souvenir and abstract, National Conference on Revier pollution and Human Health. PP.3-4

[10] Ananthakrishna Nader, P., Balasubramanian. N., Venkatachlam, T., Parabakaran , T.R.(1992). Pollution Load of Cauvery revier water . Jornal. Of Nacton.42,91-104.

[11] Areej Dalf Abbas, 2012,"Influnce of Operating Condition on adsorbtion of lead (II) From Contaminated water using different adsorbent" Eng\& Tech.Journal,Vol.3.NO.6,2012.

[12]Y. B. Zhan, A. Shukla, S. Shukls, K. L. Dorris, The removal of heavy metal from aqueous solutions by sawdust adsorption-removal of Copper, J. Hazard. Mater. 80(2000) 33-42.

[13]C. Namasivayam, K. Kadirvelu, M. Kumuthu, Removal of direct red and acid brilliant blue by adsorption on to banana pith, Bioresour. Technol. 64 (1998) 77-79.

[14]U. K. Garg, M. P. Kaur, V. K. Garg, D. Sud, Removal of hexavalent chromium from aqueous solution by agricultural waste biomass, Hazard. Mater. 140 (2007) 6068.

[15]K. Mohanty, M. Jha, B. C. Meikap, M. N. Biwas, Biosorption of chromium(VI) from aqueous solution by Eichhornia Crassipis, Chem. Eng. J. 117 (2006) 71-77.

[16]T. Karthikeyan, S. Rajgopal, L. R. Miranda, Chromium adsorption from aqueous solution by Hevea Brasilinesis sawdust activated carbon, J. Hazard. Mater. B124 (2005) 192-199.

[17]Anon, Standard Methods for the examination of Water and Wastewater, $19^{\text {th }}$ ed., Washington, DC, USA, 1995.

[18]D.C. Sharma, C.F Forster, The treatment of chromium wastewaters using the sorptive potential of leaf mould, Biores. Technol. 49 (1994) 31-40.

[19]S. Babel, T. A. Kurniawan, Low-cost adsorbents for heavy metals uptake from contaminated water: a review, J. Hazard. Mater. B97 (2003) 219-243.

[20]V. J. Inglezakis, M. D. Loizidou, H. P. Grigoropoulou, Ion exchange studies on natural and modified zeolites and the concept of exchange site accessibility, J. Colloid Interface Sci. 275 (2004) 570-576. 
[21]a) P. A. Domenico, F. W. Schwartz, Physical and Chemical Hydrogeology $1^{\text {st }}$ Ed., John Wiley and Sons, New York, 1990; b) L. N. Reddi, H. I. Inyang, GeoEnvironmental Engineering Principles and Applications, Marcel Decker Inc. New York, 2001; c) O. Nitzsche, H. Vereecken, Modelling Sorption and Exchange Processes in Column Experiments and Large Scale Field Studies, Mine Water Environ. 21 (2002) 15-23.

[22]J. Zeldowitsch, Über den Mechanismus der Katalytischen Oxydation von CO an $\mathrm{MnO}_{2}$, Acta Physiochim. URSS 1 (1934) 364-449.

[23]H. S. Altundogan, S. Altundogan, F. Tumen, M. Bildik, Arsenic removal from aqueous solution by adsorption on red mud. Waste Mange. 20(2000) 761-767.

[24]H. G. Fuhrman, J. C. Tjell, D. Mcconchie, Adsorption of arsenic from water using activated neutralized red mud. Environ. Sci. Technol. 38(2004) 2428-2434.

[25]M. Ajmal, R. A. K. Rao, S. Anwar, J. Ahmed, R. Ahmed, Adsorption studies on rice husk: removal and recovery of $\mathrm{Cd}(\mathrm{II})$ from wastewater. Bioresour. Technol. 86(2003) 147-149. 